特集 定年退職記念講演

\title{
びまん性沉細気管支炎の概念とその史的背景** \\ Diffuse Panbronchiolitis, A Disease Entity and \\ Its Historical Background
}

本間日臣*

Hromi HOMMA, M.D. F.C.C.P.

びまん性沉細気管支炎については既に多く発表 してきたので，ここでは主として本疾患の概念が 生れるまでの呼吸器病学の歴史を自らの経験を通 して述べたい。すなわち現在までのわが国の呼吸 器病学の展開と展望とを，私との関わりあいにお いて眺めてみたいと思う。

近代呼吸器病学は，1950年からつまり，20世紀 の後半から第一歩を踏みだしたと言兄よう。もっ ともこれは, 呼吸器病学のみでなく他の専門領域 すべてに共通してい劣るとである．更に医学以 外の科学全般にあてはまる事実でもある，20世紀 は科学の世紀, 工業化社会の世紀であったと後世 の人は言うであろう。次に続くものは情報化社会 の世紀と私は考光ている. その革命の波は間近に 迫っている.

ところで，20世紀の人類はそれ以前の人類の紀 元前からの，すなわち 3000～4000年分の経験を一 代のらちにしてしまいつつあると，ある人は言っ た。たとえば我々は，わずか50年の間に我々の祖 先達が過去 2000年かかって使用した地球上のエネ ルギーを消費した。すた膨大な生産量をあげた， 巨大な建造物を造った。行動半径を拡大し, 月に 到達した。地球は急速に縮少し, 食糧, 空間, 資

* 順天堂大学医学部内科学教室 (呼吸器) 教授, 現客員教授

Visiting Professor, Department of Internal

Medicine, School of Medicine, Juntendo

University

**第220回順天堂医学会学術集会〔Feb. 25, 1982〕

(May 8, 1982 受付)
源の壁が見えてきた。無限または無尽蔵のものは 地球上に存在しなくなった。この激動する変化の 速度は，速すぎて人が自主性を失わずに，冷静に 判断し，適応するいとまがなくなり，至る所にひ ずみが生じた。

呼吸器病学の進展とその中にみられる歪久梳, この様な科学と人間の歴史の急展開——進歩とは あえて言わない一死背景にした1つの反映とし て理解することが出来る.

\section{近代呼吸器病学進展の軌跡}

呼吸器病学進展の足跡は，関連する学会の歴史 の中に测みとられる。関連学会は多数あるが，こ こでは主柱となっている日本胸部疾患学会と，日 本肺癌学会とを取りあげてタよう。肺病とい党ば 肺結核と同義語であった時代は既に遠くなった。 表1にみられるよ5に日本結核病学会の設立は非 常に早く，1923年である．20世紀前半の終りまで 結核は死に至る病として死因の1位を占め続け た。結核を対象とした日本結核病学会に対し日本 胸部疾患の設立は，1961年。日本肺癌学会の発足 は，1960年である。

学会成立の機運が十分醸成されるまでル沵，相 当数の研究者の研究活動の蓄積が必要で市るか ら，結核以外の諸疾患への関心は，日本为独立 し，諸外国との門戸が開放された 1951年直後から 高まったといえる．1951年からの10年間は，当然 鎖国状態に由来した打くれを取戻すことに努力の 汇とんどが費された。 


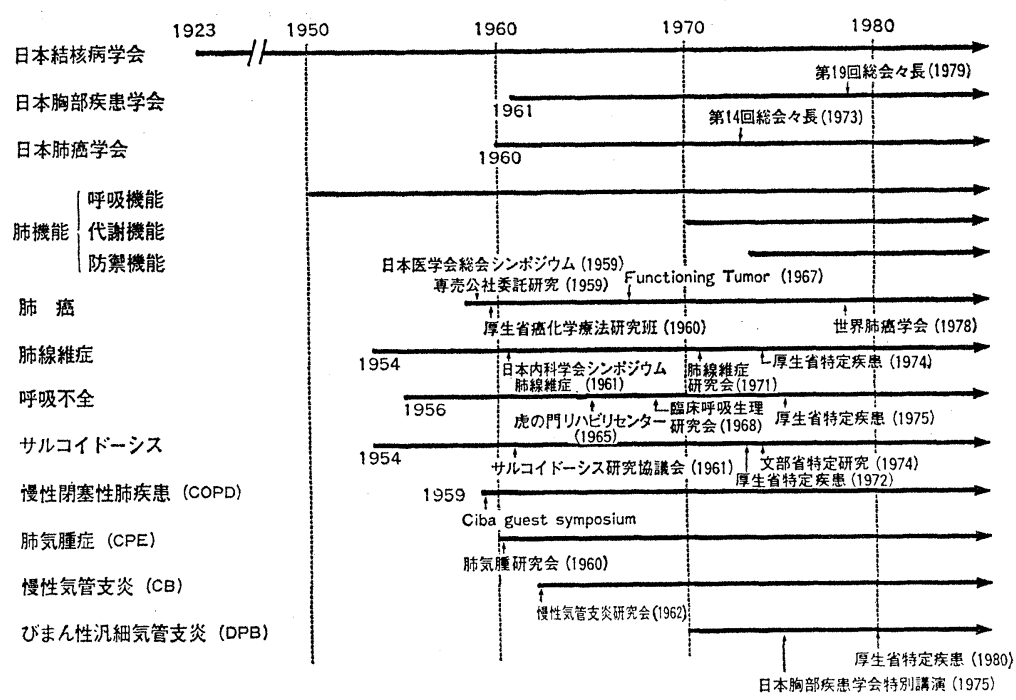

表 1 主な学会と呼吸器疾患研究の足跡

それでは，わが国をとりまく世界の情勢はどう であったか，またどの様な変貌をとげていった か，その大きな潮流を大づかみに俯瞰してみよ 5. 1950年代は, 心肺の病態生理, 呼吸機能につ いての新しい知見，検査装置の開発があいつぎ， 換気・ガス交換・肺循環に関する検査法の信ぴょ 万性と測定值の意義や解読が一定の見解に到達す るまでに払われた才月である。1956年にノーベル 賞を受けた André Cournand と Dickinson W. Richardsの功績は極めて大きいが，この為に研究 の流れは大きく呼吸生理へ傾斜することになる. 1960年代になると，呼吸機能以外の領域へ目がそ そがれ始める。肺表面活性物質の研究を契機に， 肺の代謝機能に関する仕事が増加してくる.

一方，無数の化学療法剤の出現，耐性獲得の問 題，核医学の進歩は分子生物学の進歩を背景とし た免疫機構の解明とあいまって，1970年に入る と，肺の防禦機能が視野の中に大きくとらえられ てきた。 細胞・細胞膜・細胞質内諸構造の機能に ついての知見が，諸種肺疾患の発症機構や病態之 の関連に和いて，論ぜられるようになる，今，肺 の呼吸・代謝・防期の 3 機能は, 疾患を介して形 態学との結びつきへ回帰しつつある。しかしそれ は, 分子のレベルに执いてであり, 形態学もまた
変貌したのである.

\section{はじめの留学の経験の中から}

筆者は, $1951 \cdot 52$ 年にかけて，コロンビア大学 の Chest Clinic に GARIOA Fellowship (フル ブライトの前身) の助成で留学した. 昭和 26 年の 6 月，まだ日本は占領下にあり，文部省の中庭で アメリカ軍のバスに乗り込み，横浜港へ向かい， Gen. Collins といら米海軍輸送船で渡米した. そ の夏は, シラキュース大学でオリエンテーション を受け，9月10日にニューヨークに移った．9月 6 日からサンフランシスコ 条約会議が始まり, 吉 田首相が壇上で巻物を読先姿を，シラキュースの Student Union のテレビで見た. 当時トランスコ ソチネンタルのテレビネットワークが初めて完成 したところであった。つまり，西海岸のテレビ映 像が東海岸でも見られたということが，強い印象 として残った。

ニューヨークに移ってからは，渴いた砂が水を 吸いこむように，あらゆる講演会や主な病院のカ ンファレンスに出来るだけ出て，アメリカ医学を 吸収した。当時アメリカ医学は, 現在のように全 国の平均化が未たきなれず，東高西低で，東部に 中心があった。、ーー゙ード，エール，コロソビ 
ア，コーネル，ペンシルベニアが中心で，アメリ 力医学の推進力となって㧊り, 活気がみなぎって いた。ニューヨークにいれば，全国各地の研究業 績の講演を聞くことができた。ロッキー山から大 平原を眺めるように，アメリカ医学を眺望するこ とが出来た.

余談になるが，占領下の日本では，文献を簡単 に入手できず，日比谷にあったアメリカ文化セン ターに行って，手書さで写してくることが普通だ った．抄読しょうとする論文は全文手で写した。 当時筆者は, 文化センターのない地方の人々の為 に，少しでも情報を流そうと考光，アブストラク トを作って，医学輯報という月刊紙に流したりし た．現在では想像できないことである．この手書 きで写すことのメリットは，書いているうちに訳 が出来てしま5, あるいは，文章を憶えてしまう ということ. それから，英語にもある程度堪能に なることである. ガリオア試験に合格したのもこ のおかげかも知れない. 読解力もこの時に上達し たと思う。

滞米中の経験で若い後輩諸君に伝えたいことが ある，先に砂が水を吸いこむように，米国医学を 吸収したと述べたが，ややもすると，一辺倒にな りやすい姿勢に，歯止めをかけて下さった先生の ことである. Mt. Sinai Hospital の病理の教授を して和られた，大谷貞夫先生は，当時既に人体病 理の第一人者であった。膠原病の Klemperer教授 は, あまり人体病理はされなかった。レジデント の信頼を集めていた大谷先生は，非常に反骨精神 の旺盛な, しかも頑固一徹ということでも有名だ った. 先生の許に通っているらちに, アメリカの ペーパーにずさんなものがあること，病理医師の 不足から病理報告のチェックが不十分で, インタ ーンの報告をそのま屯出してくる病院があると か, 著名な人のペーパーの中にも間違いがあるこ と等を，たくさん実例をあげて教えていただい た. 当時，学んだ大切なことの 1 つにこの論文 の読み方ということがある，読まれないで読むと いらことの重要性を, 強調して和きたい。

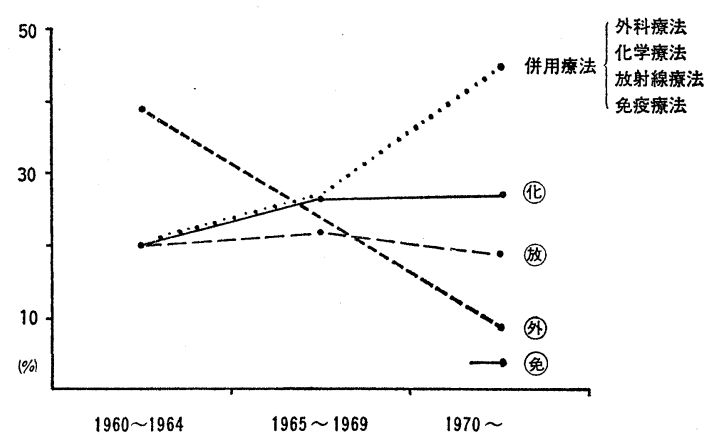

図 1 併用療法の推移

\section{主要呼吸器疾患の研究の歩み}

主な呼吸器疾患の研究の歴史を眺めてみたい. 肺癌:「100年前肺癌は知られざる疾患だった。 50年前肺癌は稀な疾㭧だった。今日肺癌は，あり ふれた病気であるとともに，きわだって重要な疾 患である」.これは 5,000 例の肺癌症例をまとめ た, ニューヨーク Memorial Hospital の Watson の言葉である.

この 100 年を 30 年， 50 年を 20 年におきか光てみ ると，日本の状況になる．30年前，呼吸機能検査 法も気管内麻酔法も未だ普及せず，肺癌は臨床講 義にも現われない稀な疾患であった。今，わが国 は3,000に近い会員を擁し，学会誌を刊行する肺 癌学会をもつ，世界唯一の国となった。1960年 来, 本学会は日本に和ける肺癌研究の索引力とな ってきた ( 1 表参照). 国際研究協力機構としての 国際肺癌学会が成立したのは，1978年である.

前述のよ5に, 日本の肺癌学会の発足は, 1960 年であるが，これに先立つ 5 年前の第 55 回日本外 科学会総会の宿題報告に, 肺腫演がとりあげられ て和り, 肺癌研究の先鞭をつけている。しかし， 内科方面でも麻酔法の進歩による肺切除の普及 や, 肺癌患者の増加に触発されて, 本症研究の機 運は高まりつつあった. 1959年学会 発足の1年 前, 第15回日本医学会総会のシンポジウムの 1 つ に, 肺癌があり, 担当者は疫学が瀬木三雄教授, 病理が大阪大学の宮地徹教授, 喫煙関係の吟味が 薬学の石館守三教授と, 病理の太田邦夫教授乱よ び, Wynder E.L.という気鋭の学者の 3 名であっ 


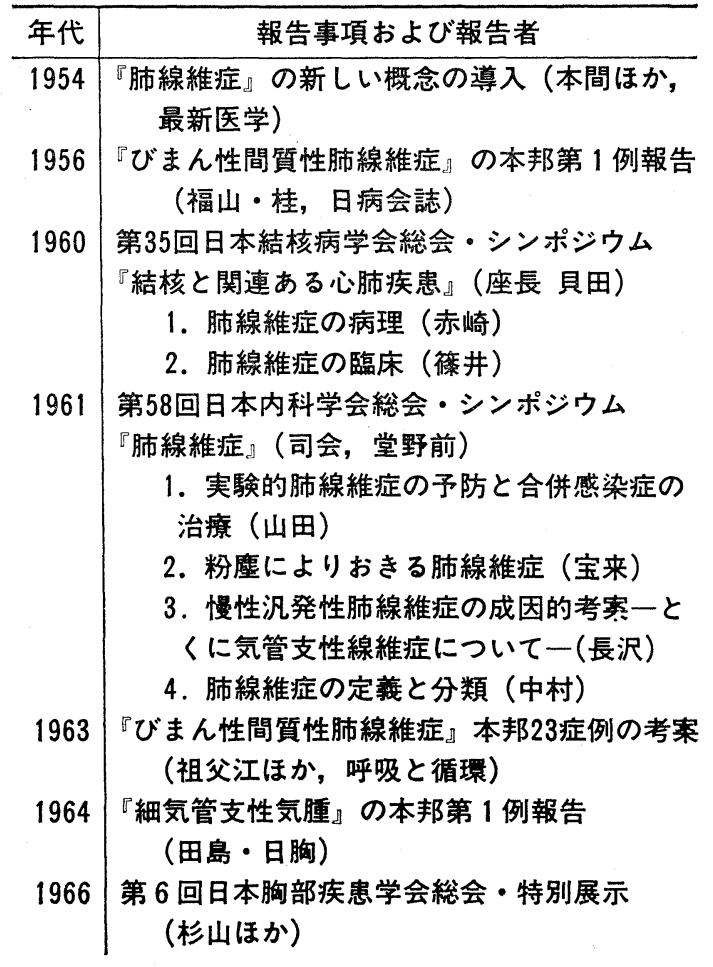

表 2 わが国に却ける近年の肺線維症研究の歩み

た。臨床の外科方面は，河合直次教授，内科方面

は，筆者が担当した.

当時まだ若輩であったけれども，冲中教授の指 示を受けて，剖検確認例 207 例の調査成績を報告 した。この時，組織型の整理に，同僚山中教授の 協力を得た。この調查により，当時の肺癌の実態 を自分なりに把握し，以後の研究の出発点になっ たと回顧する。この一年後に発足した日本肺癌学 会はまず数年を費して，臨床病期分類，組織型 分類，手術記載法，気管支鏡所見分類などを作成 し，共通の背景因子のもとでの研究成果の分析を 可能とした. 臨床病期分類が出来たのが，1965年 で，世界の肺癌の研究の足跡からみて，非常に早 い時期に属し，日本の肺癌研究が世界に先んじて いることを示すものと言光る。

1961年第 2 回肺癌学会総会のシンポジウム， 「放射線療法と化学療法」飞和いて，筆者は，化 学療法の目的は，転移の阻止であり，寿命に至る まで腫瘍との共存が可能になれば，化学療法の目

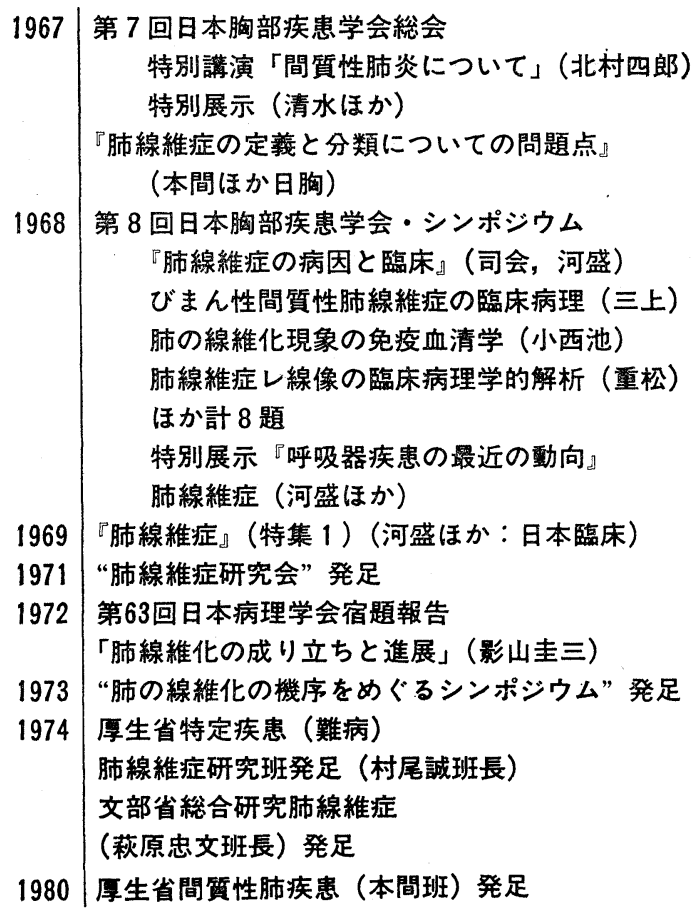

的は達成されると述べた，その手段としては，多 剂併用, 間歇且つ長期投与が患者をとこなわず に, 最大の治療効果を期待できる方法と結論し た.1961年のことである. 現在, 多剤併用は常識 となり, 免疫療法を加えた総合的, 集学的治療が 行われていることは，感概に堪えない(図 1). 図 1 は，1960年から1970年以後，この併用療法がほ とんど全例に行われ, 外科療法も, 化学療法も, 放射線も，単独療法は漂とんどなくなってきたこ とを示している.

1966年シンポ.「バチ指の発症機構の考察」, 1972年の「ホルモン異所産生及び異常酵素産生症 例についての檢討」の分担者となったことは，そ の後，一方では，遺伝子情報に関する基硶的問 題, 他万では抗腫初剂の作用機序へ, 我々の眼を 開かせてくれる絲口となった。

1982年 5 月に東京で開催された，第 3 回世界肺 癌会墥（国立がんセンタ一，石川七郎総長会長） の演題数は，390，国外240，国内150，診断に関 


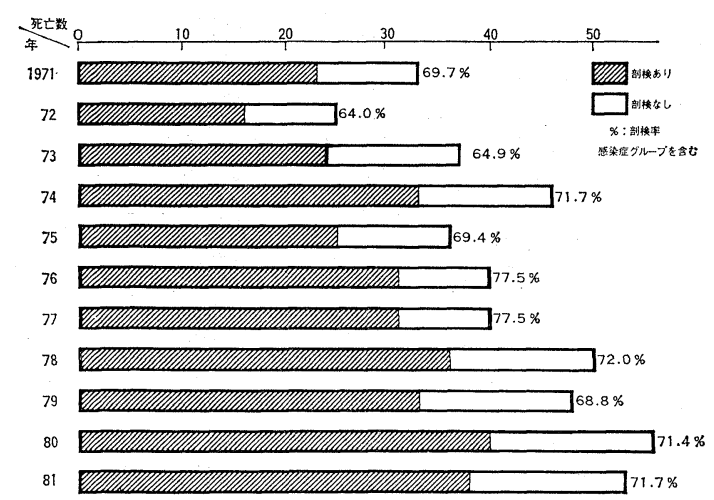

図 2 当教室過去 10 年間の死亡数と剖検率

するものが，その $1 / 4$, 治療に関するものが半数を 占めている. 出題国はほほんど地球全域をカバー し，肺癌が世界共通の重要疾患となってきたこと を示している。

サルコイドーシス：筆者と本症との出合いは, 1951年11月. 前述のニューヨーク留学中, Mt.

Fiore Hospital で Block の講義を聞き, 症例を みたことに始まる。その時，友人から，「全身病 としてのサルコイドーシスは必ず日本にもあるは ずだ」といわれた。㷌国後，1954年に本症の総説 を最新医学に発表した（表 1 ).

1961 年日本結核病学会総会 (日比野会長) の 時，本症についての第一回自由集会が行われ，司 会を命ぜられた．これと前後して，日本サルコイ ドーシス研究協議会の結成をみ，以来わが国にお ける本症研究の推進力となってきたが，1981年に 研究会の形をととの兄，第一回総会 (平賀会長) が札幌で行われた。筆者は，文部省試験研究，難 病と乙て厚生省特定疾患研究費, 文部省特定研究 費の助成を十二年間連続して受け，全国の優秀な 研究者と楽しく協同研究できた事は，誠に感謝に たえない.1963年 6 月の文部省研究会議で，筆者 は, Heilmyer の臨床病期分類に対する疑義と題 して，その理由を述べた。

1972年に始まった厚生省特定研究は，3 年の調 查研究で，わが国に和ける实態の把握，多発地区 の発見調査，ステロイドの効果評価などで成果を 得，1975年以後は，三上理一郎班長以下，精力的
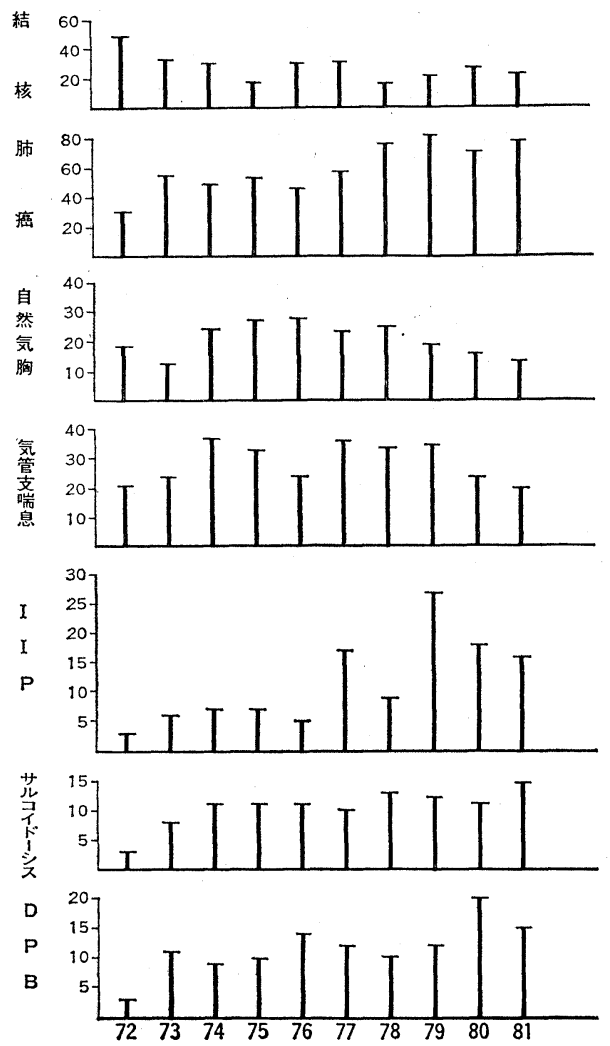

図 3 当教室過去10年間の主な疾患の推移

な研究を続行中である.

一方, 文部省特定研究難病班は, 基礎学者の久 からなる原因探究を試久，生検材料から高率かつ 高濃度に Propionibacterium acnesを分離した。 この研究は，筆者が過去半世紀に発表された病因 論の仮説を些細にみると，いずれも十分な実証を 欠いているところから，改めて確実な微生物学的 技法を駆使して，原点から洗い直してみる必要を 感じ長年あたためていたテーマであった。そし て, 特定研究開始10年前から探索を始め，1970年 〜1973年にかけて，本症患者のリンパ節から嫌気 性プロピオニバクテリウムのみが, 分離されるこ とを久ていた。特定研究助成金は，初めて基礎学 者のチームによる徹底的な探究を可能とした。こ の 6 年間の成績は, 東大出版会, 「難病の発症機、 構」になとめて報告した. 


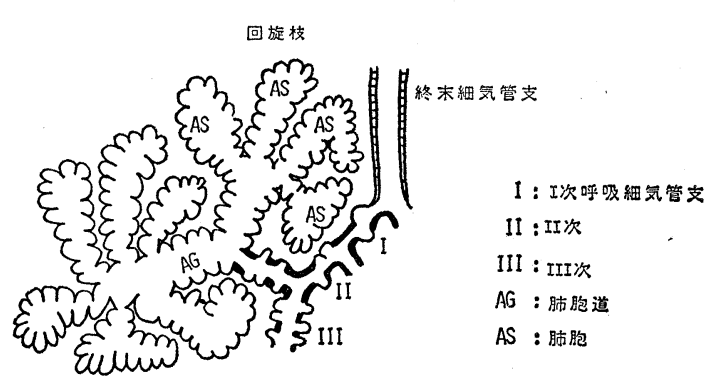

図 4 呼吸細気管支（山中）

その中で我々は，P. acnes の生物活性を明らか にし, 肉芽腫形成から線維化への生化学的過程の 解明をすすめた。この結果, 本症例にみられる類 上皮細胞肉芽腫の形成，肺に拉将る線維化，抗体 産生増強, ツ反応を含む遅延反応の抑制，自己抑 止力のみられる疾病経過など, 症状所見と $P$. acnes に関する実験成績の類似性を証明した。こ れらはすべてわが国独自の研究である.

肺線維症・びまん性間質性肺炎：本症との出合 いも1951年の留学中にさか上る. 自験症例を中心 とした総説を発表したのは，サルコイドーシスと 同様1954年で，しかも同じ最新医学誌上であった (表 2 ). 以後自験例の集積に努め，臨床例のす心゙ ては形態学的肺線維症の前段階であるびまん性間 質性肺炎であるとの見解から，スペインを初めと する1950年代の定義と分類についての疑義が生ま れてくる. 1967 年に定義と分類についての疑義を 発表した。

海外でも概念は変わりつつあり，英国では fibrosing alveolitis という呼称が用いられるように なる.1971年から肺線維症研究会が，北本教授と 五味教授の下で発足した。1973年からは，中村教 授による肺の線維化をめぐるシンポジウムが始ま った。1974年には，厚生省特定疾患調査研究班が 結成された，かくして本症の研究は急速に発展す る.

特定研究班は1980年から，間質性肺疾患と名称 を変更し，筆者が班長となり，今日のテーマであ るびまん性沉細気管支炎も研究対象となる。1954

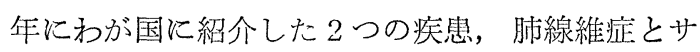
ルコイドーシスが共に難病として，特定研究の対

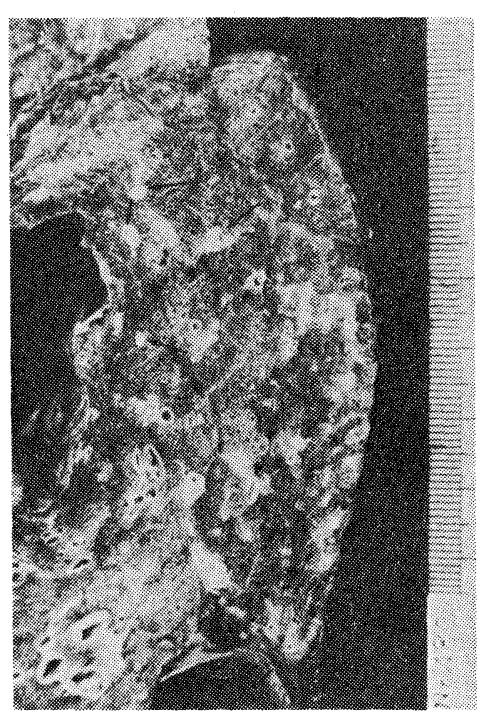

図 5 肉眼所見

矢印の白い斑点は泡沫細胞の集簇を示す

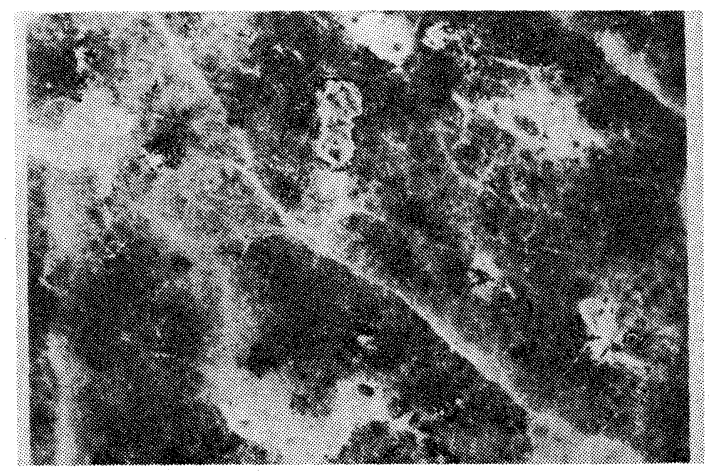

図 6 拡大.

黒点は炭粉沈着. 呼吸細気管支の疲痕狭窄部に当る. 閉塞部から中心側の細気管支の拡張がみられる。

象となり現在に至るもな和，全国的に盛んな研究 が行われているということは，誠に感無量のもの がある。

呼吸不全：第 1 回留学から帰国した時，まだ鎖 国状態から脱しきれない祖国に，留学中に得たも のを紹介しなければならないという使命感から， 2 つの訳著を出版した。 1 つはComroe の「肺機 能検查法」で，1954年に出た。他の 1 つは，Altschule の「心疾患・肺涘患の生理学」の1954年版 で, 日本に乱敄訳書の出版は1955年, 短期間の 訳出だった，当時鎌倉から通っていたので，往復 
車中の 2 時間を翻訳にあてた.

1956年に，「肺感染症と心肺危機」という報告 を,「呼吸之循環」に発表した。慢性呼吸器疾患の 終末病態としての呼吸不全は, 高令者の増加, 救 急治療法の進歩, 化学療法の進歩によって目下増 加しつつあり, 当然問題となる病態であり, 対策 が重要問題となっている.1956年の「呼吸と循環」 の特集は，わが国でこの方面の関心を表明する最 初の企画であったと思う。

虎の門病院分院がリハビリテーションセンター として開設されたのが，1965年である. ボストン のMGH (Massachusetts General Hospital) に R C Uが開設されたのが，1961年であるから，我 々はかなり早くこの方面に力を注いでことになる (表 1 参照).

第18回日本医学会シンポ.「慢性呼吸不全患者 の管理と治療」で，筆者は管理成績を発表した. この呼吸不全も，肺高血圧にひきつづき 1975年か ら厚生省特定研究の対象となって, 班研究が行わ れている。

慢性閉塞性肺疾患：これは単一の疾患名ではな い. この用語も1950年代の呼吸機能検査の普及の 産物の 1 つして生まれた。換気面で, 閉塞障害 を示す疾患すなわち気管支喘息，慢性気管支炎， 肺気腫症の咨患が，臨床上時に鑑別するのがむず かしいことから，この総称名が提案されたのであ る.

この用語は，欧米はもちろんわが国でも広く用 いられ，今に至るまで尚，みうけられるが，筆者 は当初から，形態学的に甚しく隔離した部位に病 変を有し, 症状所見の異なる疾患を一括して报う ことの意義がどこにあるのか，疑問を抱かざるを えなかった。個々の疾患の診断が可能になれば， かかる総称は不用となる. 現在この用語に, 気管 支喘息を含めるものは既にない。

わが国では, 1960年に肺気腫研究会, 1962年に 慢性気管支炎研究会が発足して䄮り, 前者は現在 に至るまで会を重ねている(表 1 )、筆者はまず, 自己の目で確かめることが先決と考光, 山中教授 之共同して, 肺気腫症, 慢性気管支炎, 気管支喘

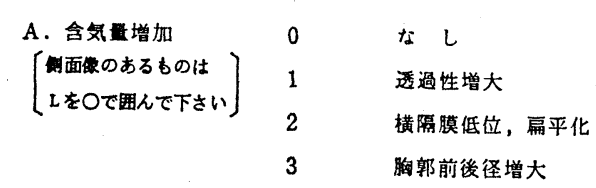

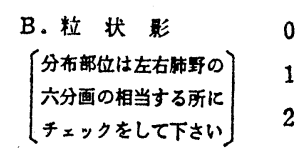

C. 肺紋理の異常

$\begin{array}{ll}0 & \text { な し } \\ 1 & \text { 太さの異常と走行の不整 } \\ 2 & \text { 肺野周辺の網状影 } \\ & \text { あるいは短い線状影 } \\ 3 & \text { 気管支壁がよくみえる } \\ & \begin{array}{l}\text { いかゆる tramline } \\ \text { および peribronchial } \\ \text { thickening }\end{array}\end{array}$
D. その他の所見 0 なと
1 境界不鲜明な大きな陰影
(畄状肺炎など)
3 その他（所見を記戒するてと）

（注）局所性の除㷧は部位を記入するとと。 判定不能な画䐝の悪いX線フイルムの場合は無理に判定しな
いで。その旨記入して下さい。

表 3 DPB飞みられるX線所見

息の臨床診断をもつ患者の剖検例を検索している らちに, 肺胞には変化はなく,すなわち肺気腫は なく，慢性気管支炎もなく，呼吸細気管支に慢性 炎症の主座があり, 呼吸機能障害が進行性に増悪 乙，呼吸不全で不良の転帰をとる症例のあること に気が付き，以後精力的に症例を集め，1つの疾 患単位として認めらることを知り，「びまん性沉 細気管支炎, 10 剖検例の臨床所見の検討」とし て, 山中・谷本・望月その他 7 名の連名で, 第 20 回肺気腫研究会に報告した.1970年のことであ る.

次で1975年の第15回日本胸部疾患学会総会 (京 大，辻教授会長)で特別講演の機会を与えられ た．1980年からは，前述したよ5に，厚生省特定 疾患調查研究の対象となり, 第 1 回全国調査で, 1,200余例が集められた. 欧米でもようやく注目さ れる機運が見られ，1982年10月の第14回世界胸部 


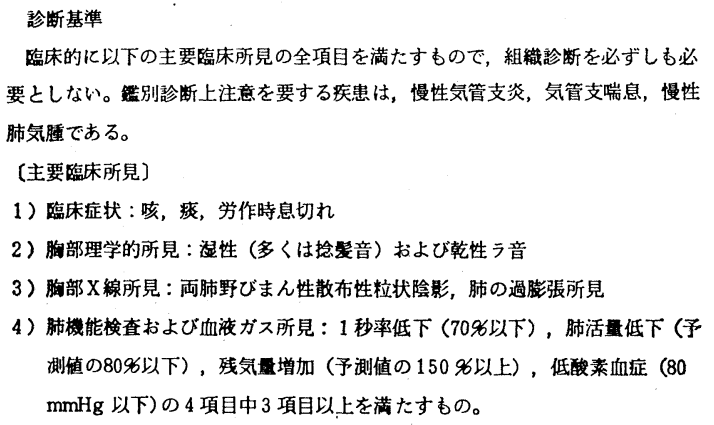

表 4 D P B の䛦断基準

疾患会議では, フォーラムの 1 つととりあげられ る予定である.

又, 近着の Thorax, に Cryptogenic obliterative bronchiolitis in adults と題した論文が出て いる.10例の症例について述べ，明らかに 1 つの 疾患単位と考光られると述べている。この報告の 内容をみると, 彰断は非常に甘く，検査も充分で ない, しかし今後, この疾患名は相当普及する可 能性がある.

このような近代呼吸器病学の激動的変遷と, 個 々の疾患の研究の進展の歴史を背景として,びま ん性沉細気管支炎の概念は生まれた。

\section{呼吸器内科における疾患の変遷}

ここでわれわれの教室で，過去10年間に扱った 疾患について触れたい. 図 2 は, 死亡例と剖検率 を示す．剖検率は 8 割を目標にしてきたが，それ までには達せず，70\%を超えたところを維持して いる. 図 3 亿疾患の種類として比較的多いものを 揭げた。びをん性沉細気管支炎は，はじめの頃か らかなりの数，つまり年閒約 20例づつみている. サルコイドーシスもかなり多い。

びまん性間質性肺炎，喘息は增減がない，肺癌 は濑増の傾向を示している。結核は病棟がなくな り，排菌のあるものは転院するので，「」には ならないが，低迷している。

\section{びまん性汎細気管支炎（D P B）}

びまん性沉細気管支炎は，呼吸細管支炎之呼ぶ

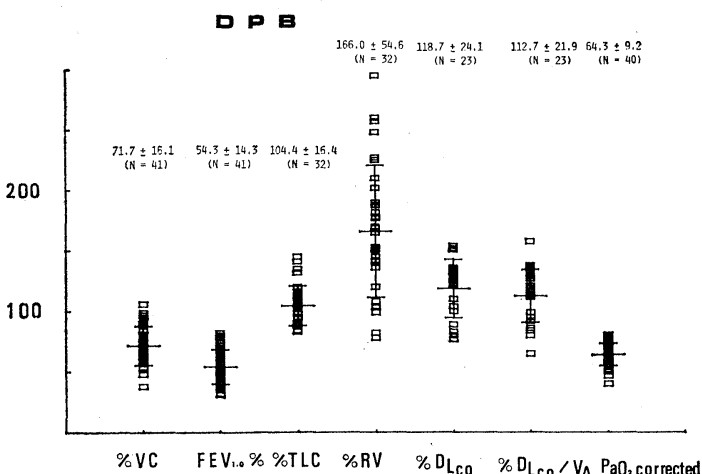

因 7 D P B の呼吸機能障害の特徴

ことが出来る，細気管支には，気道系の細気管支 と，実質系の呼吸細気管支があるので，これを混 同しない様に注意して欲しい。これを混同してい る論文がたくさんある。

D P B は，呼吸細気管支の慢性炎症である.こ れに対し，びまん性間質性肺炎は肺胞隔炎で，肺 胞隔の炎症である。汪んのわずか離れた䇢所の炎 症であるけれども，非常に違った症状所見を示す そいう点でも興味のある病気である。呼吸細気管 支は反回枝があり気流の停滞から異物が沈着しや すい場所になっている(図 4).今や我々は，慢性 気管支炎, 気管支喘息, 呼吸細気管支炎, 肺気腫 症などを区別して彮断出来るようになったのであ る.

本症の形態像は, 呼吸細気管支炎及び，呼吸細 気管支周囲炎からなる。ここで汎とは，呼吸細気 管支炎の壁が薄いため，炎症は容易に壁の全層に 及ぼのみでなく，周囲へ波及して周囲炎を随伴す るところから，沉血管炎の汎と同じ意味で，山中 教授が命名したのである。病変の発生部位からみ れば，呼吸細気管支炎と呼んでもよいかも知れな い.

図 5 は，剖検肺の肉眼所見で，白い斑点が散在 している，拡大写真では，呼吸細気管支のは九痕 狭窄が起こり，その部分に炭粉が沈着している. 㹨窄部から中心側の細気管支，むるいは気道系気 管支には，続発性の 2 次的細気管支拨張が括こっ ている(図 6 ). 組織像も呼吸細気管支炎を示し, 
病巣より末梢の肺胞は異常がない。肺気腫も，胞 隔炎もない。

次はレントゲン所見で，小さな粒状陰影の散布 が特徴である。すた，細気管支拡張がある場 合 は，管腔状陰影や，小さな輪型の影が出てくる. 表 3 は，全経過中に夕られたレントゲンの所見を まとめて表示したものである，表 4 は，全国の実 態調查に使った診断基準で，最終的には多少の手 直しがされることになっている，呼吸機能障害の 特徵は, 強い閉塞障害と, 軽度の拘束障害と, 低酸素血症である．特徵を図示する(図 7 ). 経過 は，初期には細菌感染はなく，間もなくへモ>ィ ル大が検出される。次に緑膿菌交代症を抗こし て，呼吸不全で不良の転帰をとる，非常に予後の 悪い病気である。治療の面から， 1 期， 2 期， 3 期に分けて治療を考克ている.

\section{むすびと別辞}

臨床研究には，きびしい制約が常につきまと 5。基礎実験と異なり，座標軸を制限すること も，条件を設定することも，大へんむづかしい。 生体の反応は個人差が大きく，また個々の人格 的，家庭的，社会的影響も無視出来ない. 更に， 何にも増して自らの 経験の蓄積が必要であり, べ ッドサイドの観察眼が養成されなければならな い.「書かれた医学は，過去の医学であり，目前 の患者の緻密正確な観察から，明日の医学が生ま れる」とは，冲中教授の訓えである. 新しいテー マ，新しい研究はそこから生まれるはずである。 しかしその為には，沈潜の長い年月が必要となる。 筆者は，専門医として本当の仕事がはじまるの は，40才以後と予测し，それまでもっぱら想を練 り，資料を収集し，経験を積む計画であった。し かし, 科学及び医学の発達は, 破究の成果をあげ るために，多数の專門家の学際的な協力を不可欠 なものにした。らりかえってみると，害際に仕事 が進多だしたのは，50才に近づいてからであっ た。特に過去10年間は，特定研究費の助成を得 て，長年胸の中に温めていたテーマについて，全 国の優秀な研究者と，存分に勉強できたことは，
感謝にたえない。

わが国では, 研究費の導入は, 病院よりも大学 の方が容易である．この点，13 年前に暖かく筆者 を迎光入れて自由の時間を与兄て下さった順天堂 大学のすべての方々に, 改めて感謝の誠を捧げ る. 又, 40 年間の恩師・先輩の指導, 同僚後輩の 協力にも感謝以外の言葉をみいだすことは出来な い、これなくては，現在の筆者はあり壳ないから である。

最後に一言，今後わが念願することに触れさせ て頂さたい。

\section{Members of that vanishing species,} the Old-World Idealistic, Intellectual

これは, 最初の留学からの帰国直後訳出した Altschule 著「心疾患・肺疾患の生理学」1954年 版の扉にある著者の父母への献辞である。この上 にTo My Parents と書いてある. 当時直接に Altschule に手紙を出し，このフレーズの意味を 確かめたところによれば，先の大戦後，Materialism が Idealism に Emotion (情動) が Intellect

（知性）にとって替ってしまった。旧世界の知性 ある理想主義者達は消光去ったといら感概を表現 したものといらことであった。筆者も 40 年前, idealisticなまた intellectual な，その上に romanticな旧制高校生活を経験した。そして只今 このメンバーの1人として演壇から拈りようとし ている.

\section{それではどこへ？}

Dichtung und Wahrheit の中で Goethe は, 医学を讃光，「医は全人を报う」と述べていると 記憶する。乙かし医学の専問分化が進む中で医師 自身は全人としてのバランスを言失しつつある。 筆者も例外ではない。この傾斜からの脱出と平衡 の回復とを目標としたい，単に時計を巻き戻して 前時代へ戻るのではなくて，ひたすら生存の理法 を求めたかつての romantic idealism と過去30年 間，その中に生きてきた実証主義とを止揚した更 飞高次の Idealism の境地を目指して壇を降りた いと思う。どこまで到達できるかは目下のところ 視界は「ゼロ」という他ない。 
本講演の機会を与えられた，順天堂医学会に心から感 謝する.

\section{文献}

1）本間日臣：びまん性汎細気管支炎：日本胸疾会誌， 13(7), 383, 1975.

2) M.D. Altschule : Physiology in Disease of the Heart and Lungs : Harvard Univ. Press, 1954.

3) Watson, W.L. : Lung Cancer, A study of five thousand memorial cases : Mosby Co, 1968.

4 ) 本間日臣: 肺癌の臨床一内科方面 : 第15回日本 医学会総会学術記録集, 3, 162, 1959.

5 ) 本間日臣, 吉良枝郎, 稻富恵子 : 肺癌治療の变遷

: 日本胸部臨床, 33(9), 622, 1974.

6 ）本間日臣：サルコイドーシス：最新医学, 9(9), 622,1954 .

7 ）本間日臣：サルコイドーシスの発症機構に拈ける
Propionibacterium の役割関する基礎的研究 : 難 病の発症機構, 東大出版, 245,1981 .

8 ）本間日臣, 他: 肺線維症 : 最新医学, $9(1), 116$, 1954.

9 ）本間日臣, 田村昌士，山中 晃：肺線維症の定義 と分類についての問題点：日本胸部臨床，26(11), 808, 1967.

11）本間日臣, 他 : 肺感染症と心肺危機 : 呼吸と循環, 4(1), 67, 1956.

11）本間日臣 : 慢性不全患者の管理 : 第18回日本医学 会総会会誌, 1101，1971.

12. 本間日臣，三上理一郎，山中 晃：慢性閉塞性肺 疾患：医学書院, 1975.

13. Turton C.W. et al : Cryptogenic obliterative bronchiolitis in adults: Thorax, 36, 805, 1981. 14）本間日臣：激動期の呼吸器病学々 1 つの軌跡：最 新医学, 36(6), 1021, 1977.
塩酸ニカルジピン（ペルジピン 山之内製薬）は， 臨床的飞は脳動脈硬化症, 脳出血後遺症, 脳血栓後遺 症さらに狭心症样症候群飞有効であることが実証さ れ，最近ではマイルドな降圧作用のあることから，降 圧剤の first choice として使われている、基礎的には 血管の平滑筋細胞への $\mathrm{Ca}^{++}$流入阻止することにより 血管彎縮を緩解すると考えると, 脳動脈や冠状動脈に 選択的作用するばかりで なく末梢血管抵抗も低下 し，降圧作用のほか、全身 の血管拡張作用むあると考 えられる. 我々はレイノー

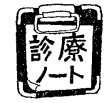
レイノ一現象及び間歇性跛行 に対するペルジピンの効果
疼痛を訴えたもの 7 例でうち 6 例が，他の知覚および 循環障害を訴えたもの 9 例のうち 7 例が自覚症状にお いてなんらかの改善を認めた. 薬䬉投与期間中，ふら つき感と顔面のほてりを訴えたものが各 1 例あった が，投与を一時中断し，その後 1 日 $20 \mathrm{mg}$ を分二投与 することによって症状は消失した.

この副作用は末梢血管抵抗の低下によるものと考兄 られる。動脈硬化を基因と する症例に改善例が多いこ とから，血管平滑筋の弛緩 作用により表在血管の拡張 や側副血管の拡張が括こり 筋血流の增加をきたしたと

想定される。一般外来でこのような血管神経症の疾病 そ遭過することは少なく，診断し治㡜することはむず かしい，我々の経験からこのような症例にペルジピン を長期間投与し，ほとんどの症例何んらかの自覚症 状の改善がみられた。一応試用すべき薬戍と考える. 今後, 他党的飞皮尿温度や指尖容積波の测定を加え症 例を重㸚检討する。

（抒茶の水相互クリニック 湘近 浩） 